\title{
COMPARING VOCATIONAL EDUCATION CURRICULA IN CHINA AND INDONESIA FOR ECONOMIC GROWTH
}

\section{Muhammad Aris Ichwanto', Mohammad Mustofa Al Ansyo- rie $^{2}$ dan Zhao Ping ${ }^{3}$}

\author{
${ }^{1}$ Universitas Negeri Malang, email: muh.aris.ichwanto.ft@um.ac.id \\ 2Universitas Negeri Malang, email: musthofansyorie.ft@um.ac.id \\ 3Beijing Normal University, email: zhaoping@bnu.edu.cn
}

\begin{abstract}
Abstrak: Asia dicirikan oleh keragaman iklim, geografi, sumber daya alam, struktur populasi, tingkat melek huruf, struktur ekonomi, dan bentuk pemerintahan. Penelitian ini dilakukan di dua negara yaitu China dan Indonesia. Karena perekonomian China dan Indonesia tetap stabil dan meningkat di tengah krisis ekonomi global, apalagi negara-negara tersebut menduduki peringkat pertama dan kedua pertumbuhan ekonomi dunia. Tujuan dari studi di bidang pendidikan ini adalah untuk menginformasikan tentang kurikulum pendidikan kejuruan yang menciptakan lapangan kerja yang terampil, kreatif, berdaya saing tinggi, mudah diserap, yang pada gilirannya mendukung pertumbuhan ekonomi di kedua negara. Kajian melalui kubus Bray dan Thomas ini memberikan kerangka analisis pendidikan komparatif yang melibatkan tiga kategori yang disusun dalam kubus. Perbandingan kurikulum sains kedua negara menunjukkan bahwa mereka sebenarnya secara umum serupa. Relatif sedikit perbedaan yang ditemukan sehubungan dengan pengetahuan yang dimaksudkan dan konten kompetensi dalam hal perbedaan diamati kuantitas keseluruhan tersirat oleh dokumen kurikulum tampaknya seimbang.
\end{abstract}

Kata-kata kunci: Pendidikan Kejuruan, Kurikulum, Indonesia, Cina

Abstract: Asia is characterized by its variety of climate, geography, natural resources, population structure, literacy rate, economic structures, and forms of government. This study was done in two countries they are China and Indonesia. Because the economy in China and Indonesia remained stable and increased amid the global economic crisis, moreover those countries were ranked first and second world economic growth. The purpose of this study in education should be to inform about vocational education curriculum that creates skilled, creative, highly competitive, easily absorbed employment, which in turn support the economic growth in both countries. This study through the Bray and Thomas cube provides a framework for comparative education analysis involving three categories arranged in a cube. A comparison of the science curricula of the two countries indicates they are in fact broadly similar. Relatively few differences were uncovered with respect to intended knowledge and competence content in the event where differences were observed the overall quantity implied by the curriculum document appeared to be evenly matched.

Keywords: Vocational Education, Curriculm, Indonesia, China

\section{INTRODUCTION}

Asian is characterized by its variety of climate, geography, natural resources, population structure, literacy rate, economic structures, and forms of goverment. Whereas some countries are highly developed, most score low on both the human and economic development indices despite their rich natural resources (Ali et al., 2020; Suharno et al., 2020). The region is the characterized by recent changes like opening up of economies and the recognition of global competitiveness, change from agrarian to industrial economies; rapid change in technology, and aspirations for economic development.

Hence, there has been an increasing recognition of the role of Technical and Vocational Education (TVE) in developing a skilled workforce. A reorientation of Technical 
and Vocatioanal Education (TVE) policies by planners and policymakers has recently taken place.(Bank, 1968; Sarjana et al., 2019; Setiawan, 2015) mentioned nearly all countries have introduced Technical and Vocational Education (TVE) in the terminal years of secondary education, in addition to the existing industrial training institutes and polytechnics, which are commonly at senior secondary or post secondary level.

Given impact of increased technological development on the environment and natural resource, Environment Education (EE) assumes special importance within the ambit of Technical and Vocational Education (TVE) (Dittrich, 2010; Djatmiko, 2016; Malik, 2018; Supriyanto et al., 2020; Tanjung, 2020). Since the graduates of Technical and Vocational Education schools enter into trades that have an immediate and direct impact on the environment, they play a crucial role in implementing practical solution to current environmental problems specialy economic problems.

This study was done in two countries they are China and Indonesia. Because economic in China and Indonesia remained stable and increased amid the global economic crisis, moreover those coutries were ranked first and second world economic growth with economic growth in 2021 by $8.5 \%$ (China) and 4.4\% (Indonesia) (Akyüz, 2017)

Meantime, undeniable economic growth in both countries because there are many factories and companies have been built, once the factor is professional workers has special skills in every China's and Indonesian factories and companies make good things and services. It means vocational education take an important role in China's and Indonesian economics and society sectors.

Tremendous influence provided by vocational education on economic sectors in the two countries is very interesting to compare, especially in vocational education curricula of both countries. The purpose of this study in education should be inform about vocational education curriculum that creates skilled, creative, highly competitive, easily absorbed employment, which in turn support the economic growth in both countries.

\subsection{LIMITATIONS OF THE STUDY}

Thisstudy there waslimitations forthescopeoftopic, objectthisstudy is vocationalschools. Vocational schools here mean vocational secondary schools and vocational high schools in China and Indonesia. And lack in this paper as some contexts are rich in data from one coutry, but lacking from the other because it was difficult to access the data from one or other country.

\subsection{SIGNIFICANCE OF THE STUDY}

Expanding access to vocational education can be an attractive option for policymakers in developing countries seeking to improve labor market outcomes. For example, Tanzania prioritized vocational education in the late 1960s (Malik, 2018; Supriyanto et al., 2020), and South Korea followed suit 30 years later, both in response to aperceived shortage of skilled workers. In both cases, expansion policy failed, primarily because parents continued to prefer general to vocational education (Dittrich, 2010; Misbah et al., 2020; Sarjana et al., 2019)

Perhaps, China and Indonesia can learn from one another, as many countries borrow education systems or ideas from each other. (Misbah et al., 2020; Zhang et al., 2020) explained that much of the field of comparative education has been con- 
cerned with copying of educational models. Policy makers in one setting commonly seek information about models elshewere, which the may choose to imitate. China and Indonsia have positive and negative qualities when it comes to their vocational education. The key is to find balance between continuity and change.

\subsection{DEFINITION}

For the purpose of this study, the following terms are defined

Curriculum - the meaning of curriculum can be understood in a narrow sense or a broad sense. In the narrow sense, curriculum is the sum total of the goals, content, range, activity, and course teaching. It can be shown through the teaching plan, teaching outline and teaching material. In the broad sense, curriculum means the total experience gained from school, which includes selecting the subjects, establishing the activities in class, the teaching process, activities after school, and the overall environment of the school (Djatmiko, 2016; Supriyanto et al., 2020; Tanjung, 2020)

Technical and Vocational Education curriculum - In a word, the curriculum of technical and vocational education includes the content of teaching in classrooms, the content of the learning after school, and the content of the students self-learning (Akyüz, 2017; Dittrich, 2010; Jin, 1993; Zhang et al., 2020). In other words, its refers to the whole program teaching and learning in technical and vocational education. The key point of emphasis is that the technical and vocational education curriculum consists of two correlative concepts: one is the apparent curriculum which means the course set in the teaching programe; and the other is the recessive curriculum which includes the material circumstance such as the building, cultural circumstances such as the classroom atmosphare, and the interpersonal circumstances such as the relationship between the teachers and students and so on (Jin, 1993; Suharno et al., 2020)

Economic Growth - An increase in the capacity of an economy to produce goods and services, compare from one period of time to another. Economic growth can be measured in nominal terms, which include inflation, or in real terms, which are adjusted for inflation. For comparing one country's economic growth to another, GDP or GNP per capita should be used as these take into account population differences between countries (Suharno et al., 2020)

\section{BACKGROUND}

\subsection{DEMOGRAPHY, GEOGRAPHY, AND ECONOMICAL}

\subsubsection{CHINA}

People's Republic of China has a population of just over 1.3 billion people, the most populated country in the world (20\% world's population). Located in East Asia, the country covers about 9.6 million square kilometers, whisch makes it the largest country by land area in world (Roll \& Ifenthaler, 2021).

The economic in china nowadays become growth very fast than the other countries and China's share of the world trade. According to the a recent WTO report real growth in GDP averaged 8.9 per cent over the period 1997-2004, whilst China's share of world trade increased to 6.7 per cent, making it the world's third largest trader after the European Union (14.5 per cent) and the US (13.6 per cent) (Dittrich, 2010). 


\subsubsection{INDONESIA}

The Republic of Indonesia is the largest archipelago country in the world, comprising 17,508 islands stretching along 5,120 kilometers from east to west, and 1,760 kilometers from north to south(Ali etal., 2020; Setiawan, 2015; Suharno et al., 2020). The islands scatter over more than one tenth of the equator between Southeast Asia and Australia, covering a land area of around 2 million square kilometers and territorial waters nearly four time of that size (Djatmiko, 2016; Malik, 2018; Sarjana et al., 2019; Supriyanto et al., 2020; Tanjung, 2020)

The national population from the 2000 national census is 206 million, and the Indonesian Central Statistics Bureau and Statistics Indonesia estimate a population of 222 million for 2006.130 million people live on the island of Java, the world's most populous island.Despite a fairly effective family planning program, which has been in place since the $1960 \mathrm{~s}$, the population is expected to grow to around 315 million in 2035, based on the current estimated annual growth rate of 1.25\% (Ali et al., 2020; Misbah et al., 2020; Zhang et al., 2020).

Indonesia is the largest economy in Southeast Asia and is one of the emerging market economies of the world. The country is also a member of G-20 major economies.It has a market economy in which the government plays a significant role through ownership of state-owned enterprises (the central government owns more than 160 enterprises) and the administration of prices of a range of basic goods including fuel, rice, and electricity. In the aftermath of the financial and economic crisis that began in mid-1997 the government took custody of a significant portion of private sector assets through acquisition of nonperforming bank loans and corporate assets through the debt restructuring process. Since 2004 the economy has recovered and growth has accelerated to over $6 \%$ in recent years (Bank, 1968). (Bank, 1968)noted Indonesia on second world economic growth with economic growth in 2012 by $6.4 \%$ after China in first rank with economic growth $8.7 \%$.

\subsection{GOALS OF TECHNIC AND VOCATIONAL EDUCATION CURRICULUM}

\subsubsection{CHINA}

With the rapid development of technology and drastic changes in the organizational form of work, the boundaries between the former subjects and vocation is broken. Multiple high-tech post need highly skilled versatile personnel. Those jobs which demand only a single skill have been reduced dramatically. What is more, with the improved productivity, pure manual labor will be replaced by more mental labor, and the posts with high intelligence have become the mainstream in the human resource market at the beginning of the 20th century. Technical and vocational education must take into account the demands of social development and students' development in order to lay a broad foundation for continual learning (Djatmiko, 2016)).

In other words, all-around development in etchnics, intellect, physique and to be highly skilled in technology with the spirit of age. In this age of knowledge-based economy, student from vocational school not only need broad knowledge and skills, but also healty vocational psycology, the thought of selft-employment and the ability to develop themselves life long. All these are the core factors need to consider in the setup of technical and vocational education curriculum (Bell, 2002; Nikolic et al., 2015; Robertson \& Briggs, 1998; TALIS, 2009)

(Djatmiko, 2016; Malik, 2018; Roll \& Ifenthaler, 2021; Supriyanto et al., 2020; Tan- 
jung, 2020) mentioned highly skilled persons need enough basic theoretical knowledge of same occupations, so the integration of culture curriculum and the tool curriculum is a kind of oriented structure. However, highly skilled persons work in the forefront of production; all the technical problems they come up againts are integrated, so the curriculum of professional technology is a kind of integrated construction.

\subsubsection{INDONESIA}

Skilled labor can contribute to the growth of the business and industrial world. Skilled workers will be involved directly in the process of production and services, so it will have a very significant role in determining the quality of the product. Skilled labor in the face of global competition need to be prepared because it will significantly affect whether or not the superiority of the product quality of business or industry in which they take part. The skilled workers who master high-tech equipment in the business or the industry will have the opportunity to work in the field, so for that school should prepare them by introducing the condition of the business or the industry because they are required to be skilled productive that can adapt to the technological advancement of science and art ((Sarjana et al., 2019).

According to the Minister of National Education (MoNE) of the Republic of Indonesia Number 22 Year 2006 on Content Standards Unit For Elementary And Secondary Education, vocational education curriculum structure is as follows: vocational education aims to improve intelligence, knowledge, personality, noble character, and life skills for independent learners and follow further education in accordance with the vocational program. In order to work effectively and efficiently and to develop expertise and skills, they must have a high stamina, expertise and master the fundamentals of science and technology, has a high work ethic, and be able to communicate in accordance with the demands of the job, and have the ability to develop themselves. In MoNE Decree No. 049074U1990, vocational educational goals outlined:

1. Prepare students to proceed to higher education.

2. Increase students skills as community members held a reciprocal relationship with the social, cultural, and around.

3. Improve the ability of students to develop self-consistent development of science, technology, and art.

4. Preparing students enter the workforce and to develop a professional attitude.

\subsection{KNOWLEDGE-BASED OF TECHNIC AND VOCATIONAL EDUCATION CURRICULUM}

\subsubsection{CHINA}

Chinese curricula are always arranged according to subjects. The subject curriculum often divides the teaching content into several subjects roudly expound the whole subject knowledge. Every subject rest on the basis of a close logical relationship and the subject logic is just the inhernt connection of the professional knowledge. The goal of subject curriculum is to let the students know the basic logical structure and the basic concept, principle and law of the subject. The systematic subject curriculum has been dominant in the academic curriculum to this day 
from start of the curricular arrangment (Bank, 1968; Jin, 1993; Wahidmurni, 2017).

In China, for many years, the method of arrangement and part of the curricular content of technical and vocational education came from liberal education (Bank, 1968). The subject curriculum ranks the subjects curriculum places special stress on the integration and system of subject. This type of subject curriculum is convenient for collective teaching, and students can learn the knowledge systematically. But the limitation of subject curriculum is obvious. Overemphasizing the integration and system of curriculum will lead to putting more emphasis on theory rather than practice. So the technical and vocational education will lose its trait. What's more, overemphasizing independence will also lead to the lack of the curicular connection (Wu and Ye,2009). Generally Chinese technical and vocational education curriculum focuses on commonnes and knowledge. The curricular structure is rigorous. It is convenient for collective teaching and good for improving students' academic quality (Wu,2007b).

At that time, modern industry was neither based on a favorable basis nor was it developed well. Because industry, especialy in its stages, was on the fringers of society, its influence on technical and vocational education was very little in comparison with the influence of traditional mainstream culture. Againts this background, technical and vocational education has been kept away from industry. So the goal and content of education rarely reflected the actual needs of industrial production ( $\mathrm{Wu}$ and Ye,2009).

The outlok on knowledge consist of two aspects: the category and the structure of knowledge, and what kind of knowledge is most valuable. Founded on the function of knowledge, Anderson (1982), Stevenson (1994), Perkins (1993) divided knowledge into three categories: Declarative knowledge, procedural knowledge, and dispositional knowledge. Declarative knowledge is about "what something is" which can be stated directly by acquiring some clues consciously. This sort of knowledge mainly comes from the outside world which is the reflection of the objective things and their internal relations. And the best method of acquiring declarative knowledge is by understanding and remembering. Procedural knowledge is about "how to do something", that is information about process and method of accomplishing some task. This sort of knowledge is based on the direct conjecture which is the outcome of practice. And it is mainly learned by actual activity. Dispoitinal knowledge is about "what is to be done". This sort of knowledge is critical. Dispotional knowledge is obtained through long-term personal experienceand emotional experience which guides the creation and exetion of the first two sorts of knowledge.

Chinese technical and vocational education emphasizes conceptual knowledge comparatively. Conceptual knowledge is the most basic knowledge about basic concept, brass tack and basic principle which can deduce a series of other knowledge. Though the relationship between conceptual knowledge and vocational training is difficult to be determined, conceptual knowledge can improve students' ability of understanding and analyzing. It is the basis of learning procedural knowledge and dispotional knowledge. It is also the basis of developing ability. Conceptual knowledge can be displayed and encoded obviously, so it is easly taught and learned, and the effect of teaching is easily checked (Wu and Ye,2009). 


\subsubsection{INDONESIA}

Generally, Indonesian technical and vocational education curriculum provide life skills include: (1) self-awareness and rational thinking skills, (2) social skills (social skills), (3) academic skills, and (4) vocational skills (Muhtadi,2012). Vocational schools provide qualified graduates knowledge who are ready to train and ready-made training program continued with further, either in industry or in addition to industry specific training institutions (Ayurai,2010).

Vocational education provide basic and general knowledge about the different types of jobs in the community while providing mental readiness to develop themselves. As well as providing basic skills to be able to adjust to any changes in the job. With the provision of vocational school graduates is expected to notonly rooted in the kind of work there, butalso encouraged to bring or create new jobs initiative and creativity to develop optimally (MoNE,2004).

\subsection{COMPETENCE-BASED OF TECHNIC AND VOCATIONAL EDUCATION CURRICULUM}

2.4.1 CHINA

The competence-base curriculum provision generally adopts a module curriculum. Students can select the appropriate unit with special aim and special need. Different modules can be integrated freely. Module curriculum has the following characteristics. The first characteristic is openness, which is embodied in the integration of modules. Students can select and integrate learning content with their own knowledge basis and interest. In choosing curriculum, teachers change the role from decision-maker to coordinators. The second caharacteristic is concrete, which is reflected in the stating of curriculum goal. Different from the abstract traditional curriculum goal, module curriculm has obvious and concrete objectives which can be expressed with measurable behaviours terms. So it can also be regarded as the criterion of evaluation. The third characteristic is invigorative. We can see it from the activating effects of module curriculum towards students' study. The advantage of module rests with terseness. The curriculum arranged with module is never detail, especially in evaluation. With the learning packages of different lengths, it can be evaluated in a short time, so each student can gain direct information feedback. Gaining acceptance of teachers, students would be inspired to learn the next part in accomplishing a part of the curriculum. (Wu and Ye,2009).

In Other hand the competence-based curriculum emphasized job competence. Technical and vocational education need to train students' job competence so that become competent for actual job (Wu,2007b). Wu and Ye (2009) generally, job competence consist of four component parts: The ability to reach technological expectation, the ability to handle emergencies, the ability to correspond with task, and the ability to adapt to job environment. Technology expectation means the expectation means the expected results required by a special vocational post and each vocational post is different in technological expectations. The ability to reach technological expectation is the core of vocational competence. The ability to handle emergencies means to cope with emergencies independently under various condition which include analysis, judgment, dicision-making, selecting solutions, carrying out action and evaluating the result. The third ability means to correspond with tasks 
according to the actual condition and the last sort of ability means to adjust to environment.

\subsubsection{INDONESIA}

In 2006, the Ministry of National Education began expanding vocational schools. According to their strategic plan (Ministry of National Education, 2006), the main reason for this policy is to increase the size of the labor force that is ready-to-work, especially among those who do not continue to tertiary education.

MoNE (2006) consider curriculum emphasized to job competence and develop competence in two areas: cognitive ability and practical ability. Cognitive ability means the ability of understanding the objective world by observation, notice, rememrance,thought, and imagination. Practical ability is operational ability, the abilty to do things, solve problems, etc. Thus creating graduates who have a high work ethic, ability to work great, and have knowledge of high technology.

Besides vocational education curriculum also emphasizes the ability to entrepreneurship and create jobs. It is in base because not all graduates of vocational education can be absorbed world of work, in addition to in order to utilize the natural resources around vocational education graduates to be more economically valuable products (MoNE,2004).

\section{CASE STUDY AND DISCUSSION OF ISSUES RAISED \\ 3.1 METODOLOGY}

This study through the Bray and Thomas cube which provides a framework for comparative education analysis involving three categories arranged in a cube (pictured below) (Adamson and Mason, 2007). For this study, the nonlocational demographic group is "others groups", the geographical/locational level is "level two: countries", and the aspect of education and of society to be studied is "curriculum" (see the pictured black cube). This framework helps to orient the reader to the elements of comparative education that will be analyzed.

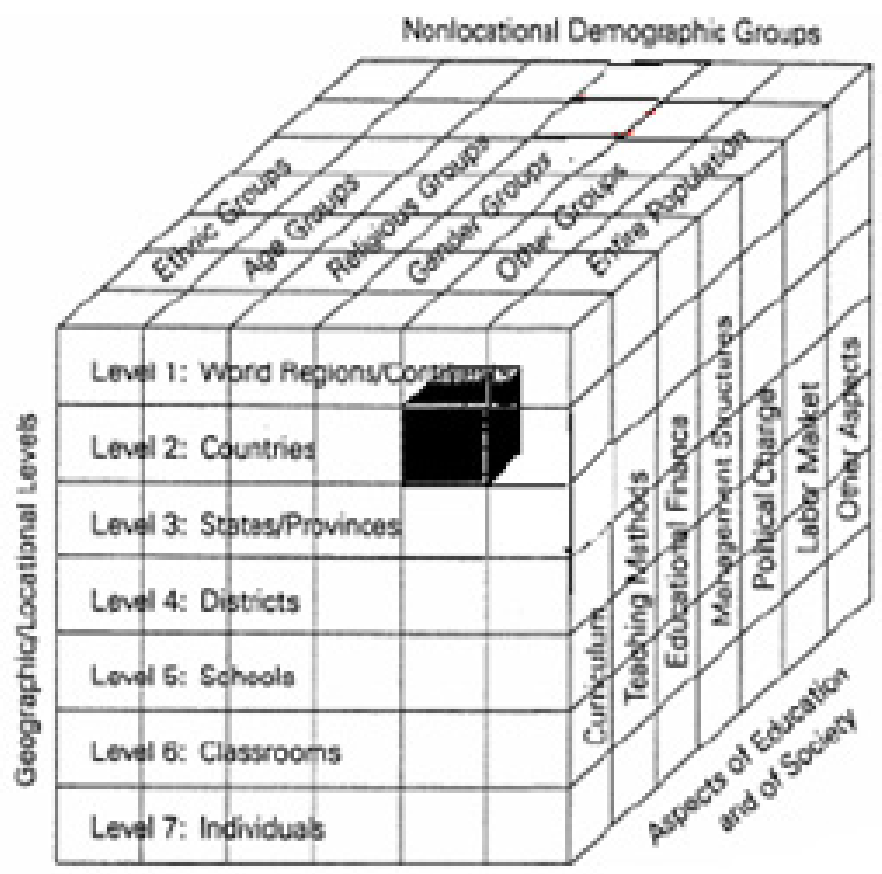

Figure 1 : Aframe Work for Comparative Education Analysis Source : Adamson and Mason, 2007 
And also this study used Ragin (1987) method there are identified three steps in this process that will be followed in this study where appropriate. First, a basic search is undertaken to identify any similarities or differences. These similarities or differences are shown to be causally relevant to the phenomenon of interest, and finally, a general explanation is provided.

\subsection{A COMPARISON OF TECHNICAL AND VOCATIONAL EDUCATION IN CHINA AND INDONESIA}

There were elements of the Chinese technical and vocational curriculum that matched to several parts of the Indonesian technical and vocational curriculum and vice versa.

For each content element of the Chinese technical and vocational curriculum a judgement was made as to whether the the Indonesian technical and vocational was more demanding, similar in demand or less demanding. Elements found not to be common to both curricula were also judged in terms of their overall demand with respect to the levels of skills and knowledge needed to access them. Where appropriate, additional local knowledge has been used to clarify uncertainties present in curricula.

In order to fully appreciate and understand the goals of the technical and vocational education curricula they must be understood in the context of the overall educational framework. As such, the national curricula for both countries begin with sections detailing the aims, values and purposes of the curriculum as a whole. These key ideas or approaches are designed to be inherent throughout all subjects detailed in the curricula, indeed as a starting point for curriculum design.

A qualitative comparison into the organisation and structure of the curriculum has been carried out in an effort to provide additional context to observed similarities and differences.

With more time, the reciprocal analysis would have been completed in an effort to avoid or minimise bias and allow for a higher degree of confidence within the qualitative comparison. To make it easier to compare the technical and vocational curricula in China and Indonesia, in this study make a comparison table adopted from Flyyn (2011).

Table 1. Comparison technical and vocational education curriculum

\begin{tabular}{|c|c|c|}
\hline & China & Indonesia \\
\hline \multirow[t]{2}{*}{ Goals Of Curriculum } & $\begin{array}{l}\text { - Technical and vocational } \\
\text { education must take into ac- } \\
\text { count the demands of social } \\
\text { development and students' } \\
\text { development in order to lay a } \\
\text { broad foundation for continu- } \\
\text { al learning. }\end{array}$ & \multirow{2}{*}{$\begin{array}{l}\text { - vocational education aims to im- } \\
\text { prove intelligence, knowledge, person- } \\
\text { ality, noble character, and life skills } \\
\text { for independent learners and follow } \\
\text { further education in accordance with } \\
\text { the vocational program. In order to } \\
\text { work effectively and efficiently and } \\
\text { to develop expertise and skills, they } \\
\text { must have a high stamina, expertise } \\
\text { and master the fundamentals of sci- } \\
\text { ence and technology, has a high work } \\
\text { ethic, and be able to communicate in } \\
\text { accordance with the demands of the } \\
\text { job, and have the ability to develop } \\
\text { themselves. }\end{array}$} \\
\hline & $\begin{array}{l}\text { - vocational school not only } \\
\text { give broad knowledge and } \\
\text { skills, but also healty voca- } \\
\text { tional psycology, the thought } \\
\text { of selft-employment and the } \\
\text { ability to develop themselves } \\
\text { life long. }\end{array}$ & \\
\hline
\end{tabular}


continuation Table 1. Comparison technical and vocational education curriculum

\begin{tabular}{|c|c|c|}
\hline & China & Indonesia \\
\hline \multirow[t]{2}{*}{ Knowledge-based curriculum } & $\begin{array}{l}\text { - technical and vocational } \\
\text { education curriculum focuses } \\
\text { on commonnes and knowl- } \\
\text { edge. The curricular structure } \\
\text { is rigorous. It is convenient } \\
\text { for collective teaching and } \\
\text { good for improving students' } \\
\text { academic quality. }\end{array}$ & \multirow[t]{2}{*}{$\begin{array}{l}\text { - Indonesian technical and } \\
\text { vocational education cur- } \\
\text { riculum provide life skills } \\
\text { include: (1) self-awareness } \\
\text { and rational thinking skills, } \\
\text { (2) social skills (social skills), } \\
\text { (3) academic skills, and (4) } \\
\text { vocational skills. }\end{array}$} \\
\hline & $\begin{array}{l}\text { - technical and vocational ed- } \\
\text { ucation emphasizes concep- } \\
\text { tual knowledge comparatively } \\
\text { which refers to the three basic } \\
\text { skills there are: Declarative } \\
\text { knowledge is about "what } \\
\text { something is", Procedural } \\
\text { knowledge is about "how to } \\
\text { do something", Dispoitinal } \\
\text { knowledge is about "what is } \\
\text { to be done". }\end{array}$ & \\
\hline \multirow[t]{2}{*}{$\begin{array}{l}\text { Competence-based Curricu- } \\
\text { lum }\end{array}$} & \multirow[t]{2}{*}{$\begin{array}{l}\text { - competence-based curricu- } \\
\text { lum emphasized job compe- } \\
\text { tence, job competence consist } \\
\text { of four component parts: The } \\
\text { ability to reach technologi- } \\
\text { cal expectation, the ability to } \\
\text { handle emergencies, the abil- } \\
\text { ity to correspond with task, } \\
\text { and the ability to adapt to job } \\
\text { environment. }\end{array}$} & $\begin{array}{l}\text { - curriculum emphasized } \\
\text { to ready-to-work, and de- } \\
\text { velop competence in two } \\
\text { areas: cognitive ability and } \\
\text { practical ability. Cognitive } \\
\text { ability means the ability of } \\
\text { understanding the objec- } \\
\text { tive world by observation, } \\
\text { notice, rememrance,thought, } \\
\text { and imagination. Practical } \\
\text { ability is operational ability, } \\
\text { the abilty to do things, solve } \\
\text { problems, etc. }\end{array}$ \\
\hline & & $\begin{array}{l}\text { - vocational education cur- } \\
\text { riculum also emphasizes the } \\
\text { ability to entrepreneurship } \\
\text { and create jobs. }\end{array}$ \\
\hline
\end{tabular}

Table adopted from Flyyn (2011).

\section{CONCLUSION}

A comparison of the science curricula of the two countries indicates, they are in fact broadly similar. Relatively few differences were uncovered with respect to intended knowledge and competence content in the event where differences were observed the overall quantity implied by the curriculum document appeared to be evenly matched. If a topic was missing from one curriculum it was replaced with another of apparently equal difficulty in the other giving continuity in breadth and depth. 
Basically the curriculum in both countries referring to the need for a highly skilled workforce, have a high work ethic and competitiveness. so it is expected that graduates of vocational education can be absorbed easily in the world of work so as to improve the quality of the product. besides vocational education curriculumbased on the needs of the world of work will makeit easier forgraduates easily getajob and contribute to economic growth in each country.

\section{DAFTAR RUJUKAN}

Akyüz, Y. (2017). Global Economic Prospects: In The Financial Crisis and the Global South (Issue June). https://doi.org/10.2307/j.ctt183pb3w.5

Ali, M., Triyono, B., \& Koehler, T. (2020). Evaluation of Indonesian Technical and Vocational Education in Addressing the Gap in Job Skills Required by Industry. Proceeding - 2020 3rd International Conference on Vocational Education and Electri cal Engineering: Strengthening the Framework of Society 5.0 through Innovations in Education, Electrical, Engineering and Informatics Engineering, ICVEE 2020. https://doi.org/10.1109/ICVEE50212.2020.9243222

Bank, T. W. (1968). Indonesia - Economic development. 1-88. http://documents.world bank.org/curated/en/1968/02/1753780/indonesia-economic-development-vol-6-6

Bell, L. (2002). Strategic planning and school management: Full of sound and fury, signifying nothing? Education Leadership and Management View project. Ar ticle in Journal of Educational Administration, February. https://doi. org/10.1108/09578230210440276

Dittrich, J. (2010). Can Indonesia Learn Something from the German Model of TVET Teacher Education ? Educationist, IV(2), 67-77.

Djatmiko, I. W. (2016). a Study on the Empowering Teachers' Professional Develop ment and Quality Assurance To Increase Teachers' Effectiveness in Vocational Secondary Schools. Jurnal Pendidikan Teknologi Dan Kejuruan, 23(2), 144. https:// doi.org/10.21831/jptk.v23i2.12297

Jin, Y. (1993). Technical and vocational education in the people's republic of china: Current status and prospects. Vocational Aspect of Education, 45(2), 135-143. https://doi.org/10.1080/0305787930450204

Malik, R. S. (2018). Educational Challenges in 21St Century and Sustainable Develop ment. Journal of Sustainable Development Education and Research, 2(1), 9. https:// doi.org/10.17509/jsder.v2i1.12266

Misbah, Z., Gulikers, J., Dharma, S., \& Mulder, M. (2020). Evaluating competencebased vocational education in Indonesia. Journal of Vocational Education and Train ing, 72(4), 488-515. https://doi.org/10.1080/13636820.2019.1635634

Nikolic, S., Vial, P. J., Ros, M., Stirling, D., \& Ritz, C. (2015). Improving the laboratory learning experience: A process to train and manage teaching assistants. IEEE Trans actions on Education, 58(2), 130-139. https://doi.org/10.1109/TE.2014.2335712

Robertson, P. J., \& Briggs, K. L. (1998). Improving Schools Through School-Based Management: An Examination of the Process of Change. School Effectiveness and 
School Improvement, 9(1), 28-57. https://doi.org/10.1080/0924345980090102 Roll, M., \& Ifenthaler, D. (2021). Learning Factories 4.0 in technical vocational schools: can they foster competence development? Empirical Research in Vocational Education and Training, 13(1). https://doi.org/10.1186/s40461-021-00124-0

Sarjana, S., Sartono, Khayati, N., Praswiyati, P., \& Warini, L. (2019). Important role vocational school to optimally implement technical and vocational education and training ( TVET ). Paedagogia: Jurnal Penelitian Pendidikan, 22(2), 148-158. https:// doi.org/10.20961/paedagogia.v22i2.35531

Setiawan, A. H. (2015). The Contribution of the Vocational Teachers' Professional Competence toward Vocational High Schools' Performance. Proceedings of the 3rd UPI International Conference on Technical and Vocational Education and Training, 14, 1-6. https://doi.org/10.2991/ictvet-14.2015.1

Suharno, Pambudi, N. A., \& Harjanto, B. (2020). Vocational education in Indonesia: History, development, opportunities, and challenges. Children and Youth Services Review, 115(May), 105092. https://doi.org/10.1016/j.childyouth.2020.105092

Supriyanto, A., Rochmawati, \& Djum Noor Benty, D. (2020). Kaizen: Quality Improve ment Innovation Higher Education in the Industrial Revolution 4.0. 381(CoEMA), 108-113. https://doi.org/10.2991/coema-19.2019.23

TALIS. (2009). Leading to Learn : School Leadership and Management Styles. Creating Effective Teaching and Learning Environments: First Results from TALIS, 189-217. https://doi.org/10.1177/2158244015570393

Tanjung, B. N. (2020). Human Resources (HR) In Education Management. Budapest International Research and Critics in Linguistics and Education (BirLE) Journal, 3(2), 1240-1249. https://doi.org/10.33258/birle.v3i2.1056

Wahidmurni. (2017). 济無No Title No Title No Title.

Zhang, J., Chen, Z. I., \& Wu, Z. (2020). RESEARCH BRIEF \# 12 An Introduction to Technical and Vocational Education in China: Implications for Comparative Re search and Practice on Internships. September. 